\title{
Pain: evaluation of the fifth vital sign. A theoretical reflection
}

\author{
Dor: avaliação do $5^{\circ}$ sinal vital. Uma reflexão teórica
}

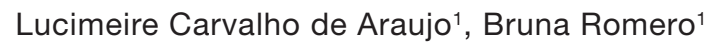

DOI 10.5935/1806-0013.20150060

\section{ABSTRACT}

BACKGROUND AND OBJECTIVES: Pain is currently a mandatory evaluation criterion for patients' evaluation because it is a prevailing symptom during disease, as well as because its management is compulsory. This is a theoretical and literary reflection aiming at validating pain as a vital sign, clarifying the painful experience and its coping and how nurses manage patients' pain.

CONTENTS: According to the literature, in spite of advances in health care pain is still a scarcely studied problem and is sometimes underestimated by health professionals during patients' assistance. This has led to theoretical reflections to develop three categories: Pain as the fifth vital sign, painful experience and coping, pain management and nursing interventions.

CONCLUSION: Patients need attention, family support and care in a broad perspective of nursing interventions to develop disease coping strategies, to control pain and to assure their wellbeing.

Keywords: Care, Nursing, Pain.

\section{RESUMO}

JUSTIFICATIVA E OBJETIVOS: A dor é na atualidade um critério obrigatório de avaliação de pacientes por se tratar de sintoma prevalente no decurso da doença, como também por ser aspecto de gerenciamento compulsório. Trata-se de uma reflexáo teórica e literária que objetivou validar a dor como um sinal vital, elucidar sobre a experiência dolorosa e seu enfrentamento e como a enfermagem gerencia a dor do paciente.

CONTEÚDO: De acordo com a literatura, apesar dos avanços na área de saúdea dor ainda se apresenta como um problema pouco investigado e por vezes subestimado pelos profissionais de saúde no atendimento ao paciente, portanto reflexóes teóricas emergiram formando três categorias: Dor: o $5^{\circ}$ Sinal Vital, a experiência dolorosa e seu enfrentamento, gerenciamento da dor e avaliação e intervenção de enfermagem.

\footnotetext{
1. Universidade do Estado da Bahia, Salvador, BA, Brasil.

Submitted in December 11, 2014.

Accepted for publication in October 16, 2015.

Conflict of interests: none - Sponsoring sources: none.

Correspondence to:

Lucimeire Carvalho de Araújo

Av. Silveira Martins Cabula, S/N

40000-000Salvador, BA, Brasil.

E-mail: lcarvalhodearaujo@yahoo.com.br

(C) Sociedade Brasileira para o Estudo da Dor
}

CONCLUSÃO: O paciente necessita de acolhimento, apoio familiar e cuidado numa perspectiva ampla de intervençóes de enfermagem, para que desenvolva estratégias de enfrentamento à doença, controle da dor e garanta seu bem-estar.

Descritores: Cuidados, Dor, Enfermagem.

\section{INTRODUCTION}

Pain is currently a mandatory criterion for patients' evaluation because it is a prevalent symptom of most diseases. The inclusion of pain as the fifth vital sign, with adequate recording and consequent intervention, assures that all patients, including terminal patients, have access to effective pain control measures.

Pain is a common symptom in cancer patients and is certainly the most feared symptom for being associated to distress and incapacities. It is estimated than 18 million people worldwide suffer due to cancer pain, being that $60 \%$ to $90 \%$ due to advanced tumors and $30 \%$ due to mild and/or moderate tumors with therapeutic possibilities ${ }^{1,2}$.

More than a symptom, pain is a disease by itself, is a subjective difficult to manage organic event and its control is the goal of the treatment. Those suffering with pain have biological, psychosocial and psychosomatic changes. With regard to common organic symptoms there are insomnia, losses in work, movement and ambulation, there are changes in mood, in concentration ability, in family relationships, in sexual activity and in other issues involving mental health. Nursing interventions for painful patients ${ }^{3}$.

Nurses have to broadly understand when there is pain and how it affects patients to be able to help them. Physicians, nurses and other health professionals must use communication techniques to establish an empathic relationship, that is, they have to learn how to put themselves in place of the other to feel their needs and to experience the world of painful patients to be able to listen to them and make a quick diagnosis to establish effective therapies for pain relief ${ }^{3}$.

It is known that notwithstanding advances in the health area, pain is still a poorly investigated problem and sometimes underestimated by health professionals. Adequate pain management comes up against frequent obstacles, such as lack of knowledge and skills of health professionals to reach analgesic control, such as concerns with opioids adverse effects, fear of possibility of drug addiction (dependence) and reluctance to accept pain complaints as human responses requiring intervention.

In this perspective, health professionals have difficulties to 
routinely evaluate and document pain, considering specific protocols for pain identification and therapy ${ }^{4}$.

Aiming at giving visibility and solvability to therapeutic pain support to cancer patients, in 2003, directives GM/MS 19 from 01/03/2002 and GM/MS 1318 from 07/23/2002 made mandatory the systematic recording of pain and its intensity in public health services ${ }^{4}$.

So, monitoring pain as the fifth vital sign makes painful response to be recognized not only as a symptom, but as a red flag demanding differentiated care patterns, and care, in turn, acts as an indicator of excellence in oncologic assistance quality ${ }^{5,6}$.

Nurses are responsible for direct care since they remain for longer time close to patients; so, they should take over pain management, especially to provide relief and better quality of life $(\mathrm{QL})^{7}$.

In light of the above, we reinforce the idea that cancer patients QL can be substantially improved if pain evaluation becomes a priority in nursing assistance planning and organization, the humanistic assumptions of which shall guide the care ${ }^{8}$.

Considering changes in daily life, working and leisure activities, in sleep and rest, in sexual life, in mood, in self-image and self-esteem, in appreciation of life, in social roles and relations, pain undoubtedly brings with it not only physiological, but also emotional, social and psychological repercussions.

Starting from this statement, it is understood that nurses concern with pain should go beyond biological aspects represented by parameters of momentary pain experience, due to individuals' social role and to relations and interactions which may cooperate for the relief of acute and chronic pain. So, the guiding question is: is pain a vital sign? How to cope with it? How does nursing manage patients' pain?

This study aimed at showing that pain is a vital sign and at explaining pain experience and its coping by nurses. According to the literature and to theoretical reflections, three categories have emerged: fifth vital sign, pain experience and its coping, pain management, nursing evaluation and intervention.

\section{PAIN: THE FIFTH VITAL SIGN}

Notwithstanding recent studies focusing on pain measurement and recording by the health team as mandatory intervention for therapy, professionals have still major difficulties to appreciate pain suffered by individuals?

Because pain is defined as a subjective and multidimensional experience, the measurement and handling of it depends both on professionals' sensitivity to notice it and on the choice of strategies to relieve symptoms, and the unpreparedness of professionals to identify pain or the negligence of its diagnosis may disqualify care.

Pain cannot be objectified but, as an organic event pain, as well as body weight, temperature, height, blood pressure and pulse, may be captured by changes in vital data and other body changes. "Painless" patients experience systemic balance wellbeing, which may be considered an internal, complex and personal experience ${ }^{10}$.

In spite of such intrinsic difficulties, why should we measure pain? Pain measurement is important because it allows health professionals to use a measure on which they shall base pain treatment or therapeutic approach, with adequate prescription and also determining treatment duration or when it should be discontinued ${ }^{10}$.

Therapy that should be used for pain and distress relief of patients by providing them with integral care ${ }^{11}$.

It is important to understand that as other vital signs, pain brings strong indications of discomfort and instability, able to unbalance vital physiologic signs and, consequently, patients' hemodynamics. So, when using classic vital signs to guide assistance to painful patients, physiological parameters stand out as the most important to be observed and recorded, for simultaneously exploring pain signs.

Nevertheless, it is observed that pain evaluation and control are still not legitimated in health institutions; it is observed that just classic vital signs measurements are part of nursing routine, while pain recording and management remain excluded from protocols to evaluate cancer patients' health situation.

Heritage/influence of positivism is strongly identified in the assistance logic of those nurses. Subjectivity involving pain evaluation and recording seems to impair the acknowledgment of its importance as vital sign deserving being appreciated and included in the planning of patients care, especially of cancer patients.

These reports ratify the need for permanent nursing team qualification, as well as for a restructuring of patients' medical charts, including the fifth vital sign - pain. This way it would be possible to address it not as something evoking a complementary therapy or as an element dissociated from body hemodynamics, but as a vital sign revealing patients' balance, comfort and wellbeing

This way, it is assured that care and comfort provided to patients with pain are as basic for nursing practice as interventions used to stabilize other vital signs.

\section{PAINFUL EXPERIENCE AND ITS COPING}

Along the years, men are progressively trying to understand the reasons for pain, aiming at getting rid of it. All people, indiscriminately, feel, felt or shall feel pain. However, most people do not know how to describe pain, which makes difficult for health professionals to really capture pain experiences of other people. This difficulty has to do with patients' resiliency: some support pain better than others ${ }^{12}$.

Pain understanding has been employed in different ways. In 320 b.C., Aristotle considered it the "antithesis of pleasure", alerting for an uncomfortable sensation. In 1895, Strang has associated sensation and reaction as two pain components. Sherrington, in 1900, has recognized the double character of the phenomenon, admitting the involvement of sensory 
and affective components in painful syndromes ${ }^{13}$.

However, most important discoveries about pain have occurred after World War II, due to the expansion of knowledge about anatomy and physiology and the use of scientific methods to investigate the meaning of pain. The need for definition of pain and of terms related to it to help universal understanding and communication has led the International Association for the Study of Pain (IASP) to constitute, in 1976, a pain taxonomy subcommittee $e^{14,15}$

The subcommittee made up of different health professionals, was chaired by Merskey and Bogduk ${ }^{16}$ and has presented in 1979 a consensus study which was appreciated by the Congress and the World Health Organization (WHO) to be included in the International Classification of Diseases (ICD). From then on, pain started to be defined as an unpleasant sensory and emotional experience, associated to real or potential injuries or described in terms of such injuries. From this definition, it emerges that the relationship between tissue injury and pain is not exclusive or direct, and that in the painful experience, sensory, emotional and cultural aspects are inseparably involved so that pain, as subjective and personal experience, has variable intensity and constancy depending on the individual expressing it $^{13}$.

In 2000, the Joint Commission on Accreditation of Health Care Organizations (JCAHO) has recommended that pain should be evaluated and recorded together with other vital signs, validating it as the fifth vital sign. Management uniformity appreciates and respects pain complaint and discomfort and consequently provides a more humanized and integral care ${ }^{16}$.

By defining pain as the fifth vital sign, the health team uses different care perspectives for pain complaints, assuring to patients the access to therapeutic interventions specific for the pain situation ${ }^{17}$.

So, adequate pain evaluation, its identification, control and relief are fundamental roles of nurses as major care providers. Knowing that human responses and pain thresholds are different from one individual to the other, pain evaluation should encompass several aspects, being focus of investigation both pain quality and intensity ${ }^{18}$.

Physical evaluation helps assuring professionals about the existence of pain, through location, duration, periodicity, evolution and response to external factors acting to aggravate or mitigate pain and other associated symptoms. However, every pain should be considered real and have diagnostic validity simply due to patients' report of its presence. In cases of pain, but where there are no verbal reports to express it, nurses should do their best to detect possible hints revealing painful experience.

Pain of one person is influenced by several factors, including previous pain experiences, anxiety, age and expectations with regard to pain relief (placebo effect). These factors may increase or decrease pain perception, and increase or decrease tolerance to pain ${ }^{18}$.

Pain may be classified as acute or chronic. Acute pain is a brief pain, characterized by twinges, mydriasis, sweating, cardiac effort and weakness, among other symptoms, requiring almost purely symptomatic approach related to presented unbalance; adequate analgesic therapy and specific interventions lead to disappearance of pain and its consequences. Chronic pain is persistent, difficult to locate, causing insomnia, anorexia, decreased libido, helplessness and anxiety $^{19}$.

In addition to being acute or chronic, pain may also be classified as nociceptive and by deafferentation. This differentiation is important because it defines treatment differences. Nociceptive pain is that where there is high synthesis of algiogenic substances and intensive stimulation of nociceptive fibers, such as in case of inflammatory, traumatic or ischemic diseases. Neuropathic pain, or pain by deafferentation, occurs when there is total or partial injury of peripheral or central nervous system nervous pathways, such as diabetic neuropathy, herpes zoster, stroke, and structural invasion by tumors, among other situations ${ }^{20}$.

Pain is a sensation, but is also an emotional phenomenon leading to escape and protection behaviors; it should be understood as a very complex phenomenon with biological, intellectual, emotional and cultural variations ${ }^{17}$.

Pain is knowingly the major stressor factor, which justifies the use of pain control protocols as alternative to help promoting some interventions for its relief, such as pain evaluation at regular intervals every six hours or according to the evaluation of vital signs; use of specific pain intensity evaluation scales according to the needs of each patient, use of non-pharmacological actions for its control, analgesic protocols established in the literature.

Pain as the fifth vital sign: actions of the nursing team in the private hospital managed by the Single Health System $(\text { SUS })^{21}$.

Pain evaluation involves clinical exam (history of the disease, physical evaluation, laboratory and imaging tests), pain experimentation characteristics, repercussion of pain on daily life activities and investigation of significant psychic and sociocultural elements for the presentation. This is possible with the implementation of pain evaluation and handling protocols, as well as with the acquisition of knowledge and training by the nursing team ${ }^{13}$.

Pain may be evaluated by means of patients' reports, observation of their behavior and physiological responses to pain $^{19}$. Evaluation scales are pain measurement tools and may be classified as one-dimension or multidimensional. One-dimension scales evaluate just one dimension of pain and among the most popular, there are numeric visual scale (NVS) and visual analog scale (VAS). NVS is graded from zero to 10 , where zero means no pain and 10 the worst imaginable pain. The advantage of this tool is that it is familiar to participants since human beings use numbers since childhood. VAS is a straight line, with no numbers, indicating in one edge "no pain" and in the other "worst imaginable pain" ${ }^{10,22}$.

There are also non-numeric quantitative scales, facial expression scales with increasing distress or of "sequence of 
glasses" and hands scale. The former graduates pain intensity by means of a glass of water, being the empty glass equivalent to no pain and overflowing glass equivalent to pain 10; the latter follows hands position were the removal of hands from the praying position evidences increased pain. These scales are useful for patients with low school education and for those with difficulties to understand the numeric scale ${ }^{20}$. Another way to graduate pain is the behavioral scale where a score is given by directly asking patients about their remembrance of pain as a function of their daily activities. Score zero is given when patients have no pain; score three when there is pain with periods in which it is forgotten; score six when pain is not forgotten, but also does not impair daily life activities; score eight when pain is not forgotten and impairs all activities except for feeding and hygiene; and finally score 10 when pain persists even at rest, is present and cannot be ignored ${ }^{17}$.

However, painful experience is not limited to its intensity, being much broader. The coverage need for this reality has led to multidimensional scales for pain evaluation. Most widely used pain questionnaire is the inventory developed by Melzack (1975), in the McGill University. This questionnaire has 78 descriptors of pain sensory qualities, in addition to a drawing where patients mark pain location, and of a pain intensity scale.

A criticism to multidimensional pain evaluation tools is that they are complex, difficult to apply in the clinical practice and difficult to be understood by patients. So, the most important factor to choose the tool to be used is patients' ability to understand it; so, evaluation tools should be adequate to age groups, to cognitive capacity and to cultural aspects of evaluated individuals ${ }^{1}$.

It is desirable to use multiple interventions providing better analgesic response, since they may simultaneously interfere with nociceptive impulse generation, with pain transmission and interpretation processes and with pain suppressing system stimulation.

Pain management is complex and its success demands multiple efforts from the health team to reach satisfactory results. Relaxation, hypnosis and distraction techniques, therapies with ice and heat, massage and skin stimulation, guided imaging, among others, are some examples of non-pharmacological measures which have desirable effects ${ }^{23}$.

\section{PAIN MANAGEMENT - NURSING EVALUATION AND INTERVENTION}

Pain evaluation has been a challenge for oncologic nursing with regard to diagnosis and follow-up of the distress of individuals living with pain.

Understanding that pain is both an individual and social experience lived beyond physical body, very often it cannot be integrally captured or expressed by means of words ${ }^{19}$, so pain meaning has to be evaluated by nurses by reading body language, as well as by other aspects which point to pain signs and symptoms, fact which requires caution, attention and effort of professionals for adequate screening ${ }^{24}$.

For such, it is understood that pain identification would be the first step for adequate recording of the type of pain, its intensity and repercussion on QL of cancer patients.

Descriptions of chronic pain signs in cancer patients by nurses follow their knowledge, beliefs and values. So, among features allowing pain identification, most frequent were changes in face expression, changes in mood and behavior.

These features taken as basis for pain perception are important pain hints and references for analgesic therapy, however they are not enough for a more precise pain diagnosis.

Professionals should understand patients' distress by their stereotyped behavior, such as crying, moaning, agitation and shivering.

Nurses should be able to recognize/identify "pain hints", which is undoubtedly not an easy task since patients and professionals may have different perceptions on pain.

Patients may react in the most different ways to pain, so the professional approach of getting close, conquering, attentive listening and systematic observation may help the identification of pain symptoms and adequate assistance planning. Pain is not easy to be diagnosed since it is an individual and subjective phenomenon, the interpretation and expression of which involve cultural, sensory and emotional elements which require professional efforts with regard to knowing pain stimulation and response mechanisms ${ }^{11}$.

Nurses should evaluate painful patients based on the nursing process, to investigate and obtain data allowing pain identification and diagnosis. This way, they will develop skills to identify patients' needs and nursing practice will be adequate.

The implementation of pain evaluation and handling protocols, as well as the acquisition of knowledge and training by the nursing team will facilitate pain management and therapeutic efficiency ${ }^{13}$.

Care of acute pain is directly related to the implementation of pain evaluation and handling protocols, as well as to the acquisition of knowledge and training by the nursing team ${ }^{25}$.

Nursing care planning should not be underestimated because it defines the art and the science of the profession. If nurses continue to work in the traditional way, they will continue to be defined by what they do and not by what they have really built in terms of theoretical-practical knowledge ${ }^{26}$.

For nursing assistance to contemplate human response to pain and its meaning for those suffering it, it has to include pain as evaluation item, that is, as a parameter leading nurses taking care of cancer patients to provide more humanized and quality care.

In this perspective, empirical and daily learning of those dealing with cancer patients is not enough for the planning of nursing assistance to meet health specificities and care of such patients. Pain evaluation tools are necessary and mandatory to direct nurses' actions. Tully, Pinheiro \& Teixeira ${ }^{7}$ have confirmed the need for history and physical evaluation, by including in their practice pain evaluation, its intensity, 
location, type, beginning and duration, factors relieving or worsening the effect of therapies, in addition to patients' complaints.

Pain experience, as observed by this study, is an example of a broad symptom, not limited just to intensity, location, type, beginning and duration. It also involves other pain characteristics which should also be evaluated, such as site, irradiation, periodicity and triggering factors. It is important to observe pain behavioral and physiologic reactions, such as face expression, uneasiness, protective position, insomnia, anxiety, irritability, sweating, paleness, tachycardia, tachypnea and hypertension, among others ${ }^{12}$.

Uncontrolled pain results in respiratory, hemodynamic and metabolic changes, predisposing patients to cardiovascular instability, higher energy and protein consumption, difficulty to early ambulate, favoring the appearance of deep vein thrombosis, especially in the elderly, it causes insomnia, higher metabolic wear, fatigue and less motivation to cooperate with treatment ${ }^{21}$.

Due to its broad symptoms, pain affects individuals in their hearts and very often makes them weak and needing support and understanding.

Family involvement and its participation in assistance are highly significant to integrate knowledge health professionals already have to those necessary to the holistic care of painful patients.

For living with the patient, family members are able to translate behavior and feelings changes and pain expressions of the patient, thus cooperating with the team in the therapeutic approach. So, it is part of nursing assistance to jointly evaluate patient and family reports, their attitudes, postures and expressions which may evidence a symbolic communication of pain.

Family information is a major tool for health professionals to understand how pain is processed and is relevant for nursing planning and decision.

Notwithstanding the acquisition of family information on patient's condition and more specifically on pain, it is poorly appreciated and used by nurses in systematic and incisive way. However, for being part of the care of patients and their families, professionals have no way to deny the value of the individual-family integration for pain investigation, being implicit that professionals make use of so-called "unqualified" information of the escort-family member to conduct the therapeutic process ${ }^{12}$.

Considering the family as a system, the appearance of a severe disease in a beloved one shall lead to a reorganization in its structure and distribution of roles ${ }^{27,28}$.

Recognizing the family as care provider, asking support to identify pain symptoms of cancer patients is extremely relevant since, in general, family members are those daily living the disease together with the patient. Based on individualfamily interaction patterns, it was conjectured that for belonging to the individual, the family is able to detect subtle life changes caused by the disease, as well as behavioral and/ or physiological changes caused by pain.
We reinforce the need for considering a set of factors interacting with chronic pain processes and family strategies to take care of cancer patients. It is necessary that nurses make all family members co-responsible for cancer patients' therapy, encouraging them until they feel safe and confident, because this is a very important step to advance in the appropriations of individualized care.

Understanding pain as a syndrome resulting from the interpretation of the physical-chemical aspect of the nociceptive stimulation and of its interaction with individual characteristics such as mood, cultural and affective aspects of individuals ${ }^{8}$, we reinforce the value of therapeutic communication commented by some respondents. Professionalpatient interaction should always be of encouragement and stimulation, aiming at transmitting to patients the sensation that their pain is being understood and may be controlled. Remaining therapeutic measures, less frequently mentioned by nurses for pain relief were cryotherapy, changes in position, use of warm water compress, evaluation of drug tolerance, comfort massage, decreased noise and light, in addition to the use of placebo.

In light of the answers, it follows that nurses, basically, are restricted to analgesic drugs and emotional support to deal with patients' pain complaints, even having access to other easy to apply analgesic resources.

Pain relief is a basic human need, a human right and so it is not only a clinical issue but also an ethical situation involving health professionals.

There are many nursing interventions which may be offered to patients for them to develop the functional capacity and survive without pain, such as: correlating pain and its intensity to prescribed analgesics; control its efficacy and adverse reactions; abolish "if needed" prescription schemes; give preference to oral route for the administration of analgesics because in addition to being effective and accessible, it is less expensive and has low risk potential; use alternative measures of image building, respiratory exercises and massage; promote physical, psychic and spiritual comfort; transmit confidence to patients; emotional support, help family to ideally react to patient's pain experience ${ }^{7}$.

In addition, nurses have broad competences which contribute for patients' recovery. Among such therapies, there are music therapy, therapeutic massage, stimulation of thoughts relieving pain, aromatherapy and positioning for comfort ${ }^{29}$. Ongoing education is critical for pain management by nurses because technological advances are constant, the development of analgesic techniques and equipment is increasing, and this requires team update for diagnosis, follow-up and intervention $^{30,31}$.

\section{CONCLUSION}

The importance of establishing pain as the fifth vital sign is unquestionable, especially in oncology, since disease impact is global. Systematic pain monitoring is a resource helping communication between health team and patients, coop- 
erating with patients' survival and QL and also decreasing their hospital stay.

One may conclude that pain negatively interferes with daily life activities of people, and that it has to be immediately understood as the fifth vital sign to be adequately controlled. Nurses provide limited care to pain, thus leading to inadequate pain management and below patients' demand.

Most nurses do not master pain mechanisms, relying on behavioral parameters for pain identification due to unawareness of pain measurement scales and they also base nursing pain relief therapies on medical models. These findings show the need for emergency educative processes so that nurses may develop a periodic and updated qualification in oncologic nursing for the problem of pain.

Amidst reflections, there is also the proposal to restructure nursing course graduation curricula, including pain and its correlates, aiming at subsidizing students with pain management in the care process.

We stress that patients need attention, family support and care in a broad perspective of nursing interventions, for them to develop strategies to cope with the disease, control pain and assure their wellbeing.

\section{REFERENCES}

1. Chaves LD. O enfermeiro no manejo da dor do câncer. Associaçấo Brasileira de Cuidados Paliativos (ABCP) 2004

2. Kipel AG. Prevalência da dor: mitos, medos e desacertos relacionados ao uso de analgésicos opiáceos. Texto Contexto Enferm. 2004;13(2):303-8.

3. Centro integrado de tratamento da dor. Disponível em: http://centrodetratamentodador.com.br/?p=616.Acesso 29/04/2015.

4. Lopes LB, Souza MI, Pereira ME. Dor - $5^{\circ}$ sinal vital: Análise do Conhecimento da Equipe de Enfermagem. 57 Congresso Brasileiro de Enfermagem. Goiânia, 2005. http://www.abennacional.org.br/57CBEn/apresentacao.html.

5. SBED. Sociedade Brasileira para o estudo da dor. Projeto Brasil sem dor. São Paulo, 2005. Disponível em: www.dor.org, acesso em: 25.03.2014.

6. Diccini S. Dor como $5^{\circ}$ sinal vital. Acta Paul Enferm. 2004;17(1):7-8

7. Tulli AC, Pinheiro CS, Teixeira SZ. Dor oncológica: os cuidados de enfermagem. RevBrasCancerol. 1999. Disponível em: http://portaldeenfermagem.blogspot.com. br/2008/07/artigo-dor-oncolgica-os-cuidados-de.html Acesso em 22/05/2015.

8. Gutiérrez MG, Arthur TC, Fonseca, SM, Matheus MC. O câncer e seu tratamento: impacto na vida dos pacientes Online Braz J Nurs. 2007;6(0).
9. Sousa FA. [Pain: thefifthvialsign]. RevLatAm Enfermagem. 2002;10(3):446-7 Portuguese

10. Bottega FH, Fontana RT. A dor como quinto sinal vital: utilização da escala de avaliação por enfermeiros de um hospital geral. Texto Contexto Enferm. 2010;19(2):283-90.

11. Pimenta CA, Cruz DA. Crenças em dor crônica: validaçáo do Inventário de Atitudes frente à dor para a língua portuguesa. RevEscEnferm USP. 2006;40(3):365-73.

12. Pedroso RA, Celich KL. Dor: quinto sinal vital, um desafio para o cuidar em enfermagem. Texto \& Contexto Enferm. 2006;15(2):270-6.

13. da Silva LM, Zago MM. [Care for theoncologicpatientwithchronicpainfromthe point ofviewofthe nurse]. Rev Lat Am Enfermagem. 2001;9(4):44-9. Portuguese.

14. Booss J, Drake A, Kerns RD, Ryan B, Wasse L. Pain as the 5th vital sign [toolkit on the internet]. Illinois: Joint Commission on Accreditation of Healthcare Organizations; 2000 Disponívelem: http://www.va.gov/oaa/pocketcard/pain5thvitalsign/ PainToolkit_Oct2000.doc. Acesso 16/05/2015.

15. Pavani NJP. Dor no Câncer. RevSocBrasCancerol. 2000;3(12):42-52.

16. Merskey H, Bogduk N. Classification of Chronic Pain, $2^{\text {nd }}$ ed, IASP Press, Seattle: 1994. Disponívelem: http://www.uptodate.com/contents/definition-and-pathogenesis-of-chronic-pain. Acesso 11/05/2015.

17. Boss J, Drake A, Kerns RD, Ryan B, Wasse L. Pain as the $5^{\text {th }}$ vital sign. [toolkit on the internet].Illinois: Joint Commission On Accreditation of Healthcare Organizations; 2000.

18. Calil AM, Pimenta CA. [Painintensityofpainandadequacyof analgesia]. RevLatAm Enfermagem. 2005;13(5):692-9. Portuguese.

19. Ribeiro MA, Lopes MH. [Development, implementationandevaluationof a distancecourseaboutwoundtreatment]. RevLatAm Enfermagem. 2006;6(3):77-84. Portuguese.

20. Vasconcellos MH. Ante a impossibilidade de sustentar a dor, a insustentabilidade do ser. CadPsicanál. 2005;21(24):199-218.

21. Pimenta CA, Partinoi AG. Dor e cultura. In: Carvalho MM (organizador.). Dor: um estudo multidisciplinar. Sáo Paulo; Summus: 1999. 159-73p.

22. Marconi MA, Lakatos EM. Técnicas da Pesquisa: planejamento e execuçăo de pesquisas, amostragens e técnicas de pesquisas, elaboração, análise e interpretaçáo de dados. 5a ed. Săo Paulo: Atlas; 2002.

23. Saça CS, Carmo FA, Arbuleia JP, Regiane CX, Alves AS, Rosa BA. A dor como $5^{\circ}$ sina vital: atuação da equipe de enfermagem no hospital privado com gestâo do Sistema Único de Saúde (SUS). J Health Sci Inst. 2010;28(1):35-41.

24. Sampaio LR, Moura CV, Resende MA. Recursos fisioterapêuticos no controle da dor oncológica: revisão de literatura. RevBrasCancerol. 2005;51(4):339-46.

25. Lasaponari EF, Costa AL, Peniche AC, Leite O, RCB de Revisão integrativa: dor aguda e intervençōes de enfermagem no pós-operatório imediato. SOBECC, São Paulo. jul./ set. 2013; 18(3):38-48.Disponível em: www.sobecc.org.br. Acesso em 29/11/2015

26. Nascimento LC, Rocha SM, Hayes VH, de Lima RA. [Childrenwith câncer andtheirfamilies]. RevEscEnferm USP. 2005;39(4):469-74. Portuguese.

27. SalvettiMde G, Pimenta CA. [Chronicpainandthebelief in self-efficacy]. Rev. Esc. Enferm.USP. 2007;41(1):135-40. Portuguese.

28. Barbosa FS, Valle IN. Pain in newborns: a descriptive study about assessment and non-pharmacological treatment at a NICU. Online Braz J Nurs. 2006;5(2) Disponível em: http://www.objnursing.uff.br/index.php/nursing/article/view/337. Acesso em: 22 de maio de 2014

29. Rossato LM, Jacob Y. Dor crônica em crianças com tumores ósseos. Rev Mineira Enf. 2006;10(3):287-91.

30. Romanek FA, Avelar MC. A multidimensionalidade da dor no ensino de Enfermagem em atendimento pré-hospitalar, às vítimas de trauma. Rev Dor, 2012;13(4):350-5.

31. Paula GR, Reis VS, Ribeiro FA, Gagliazzi MT. Assistência de enfermagem e dor em pacientes ortopédicos na recuperaçâo anestésica, no Brasil. Rev Dor. 2011;12(3):265-9. 